\title{
Markers Of Arrhythmia In Patients With Left Ventricular Outflow Tract Stenosis And Coartation Of Aort
}

\section{Sol Ventriküll Çıkış Yolu Darlığı Ve Aort Koarktasyonu Olan Olgularda Aritmi Belirteçleri}

\author{
Özlem Saraç Sandal ${ }^{1}$, Timur Meșe ${ }^{2}$, Rahmi Özdemirr², Cem Karadeniz ${ }^{3}$
}

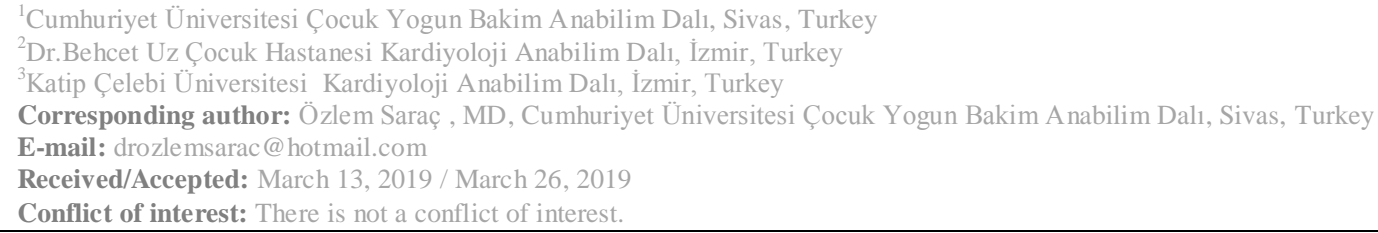

\section{SUMMARY}

Objective: Arrhythmias due to congenital heart diseases are found to be the second most common cause of mortality after ischemic heart diseases in several studies. Coarctation of the aorta, hypertrophic cardiomyopathy and aort stenosis increase afterload of the left ventricle and as a result of this, they cause an increase in wall stress in the early and hypertophy of the wall in the late phase. This condition leads a corruption in ventricular and atrial conduction and predisposes to arrhythmias. In this study, we intended to examine the risks with indicators like P dis, QT dis, Tp-e for arrhythmias in diseases with left ventricular outflow tract stenosis in children.

Method: 101 patients with with left ventricular outflow tract stenosis (coarctation of the aorta, idiopathic hypertrophic subaortic stenosis, hypertrophic cardiomyopathy and aortic stenosis) in pediatric age group who were diagnosed between 2008-2014 in Dr. Behçet Uz Children's Training and Research Hospital were included in this study. 110 healthy children were included in this study as a control group. Pdis, corrected QT, QT dis ve Tp-e and Tp-e /QT indices in both groups were were calculated and compared using standard 12-lead ECG.

Results: P max, corrected QT, Pdis, QTdis, Tp-e and Tp-e/QT in patient group were found to be significantly higher than the control group. There was no difference between sub-groups of patient group according to Pmax, corrected QT, $\mathrm{P}$ dis, QT dis, Tp-e and Tp-e/QT. There was also no difference between beta blocker users and non-users according to $\mathrm{P}$ max, corrected QT, P dis, QT dis, Tp-e and Tp-e/QT.

Conclusions: High P max, corrected QT, P dis, QT dis, Tp-e and Tp-e/QT in the patient group showed the risk for ventricular arrhythmias and atrial fibrillation in patients with left ventricular outflow tract stenosis.

Keywords: arrhythmias, sudden cardiac death, dispersion, electrocardiography

\section{ÖZET}

Amaç: Konjenital kalp hastalıklarına ait aritmilerin ani kardiyak ölüm riski açısından iskemik hastalıklara bağlı aritmilerden sonra en sık mortalite nedeni olduğu gösterilmiştir. Aort koarktasyonu, hipertrofik kardiyomyopati ve aort stenozu gibi hastalıkların varlığında sol ventikül ard yükü belirgin artmakta bunun sonucu olarak da erken dönemde artmış duvar stresi ve geç kompansatuvar ventrikül hipertrofisi ortaya çıkmaktadır. Tüm bunlar da ventrikül ve atriyal iletimi bozarak aritmilere yatkınlık olușturabilmektedir. Bu çalıșmada, çocukluk çağında sol ventrikül çıkıș yolunda darlığa yol açan kardiyak patolojilerde aritmilere yatkınlığın ortaya konması amaçlanmıştır.

Yöntem: 2008-2014 yılları arasında tanısı konan ve hastanemizde izlenen sol ventrikül çıkış yolunda darlığa neden olacak kardiyak patolojisi olan 101 hasta çalıșmaya dahil edildi. Kontrol grubu olarak 110 sağlıklı çocuk alındı.

Standart 12 derivasyonlu EKG'de hastaların P dispersiyonu(dis), QTd(değişkenlik), QT intervali, QTdis ve Tp-e ve Tpe /QT indeks değerleri hesaplandı.

Bulgular: Hasta grubunda Pmaks, QTd, Pdis, QTdis, Tp-e ve Tp-e/QT indeksleri kontrol grubuna göre belirgin yüksek saptandı. Hasta grubunu oluşturan alt gruplarda Pmaks, QTd, Pdis, QTdis, Tp-e ve Tp-e/QT indeksleri açısından gruplar arası anlamlı istatistiksel fark saptanmadı. Beta bloker kullanan ve kullanmayan hasta gruplarında da bu parametreler açısından anlamlı fark saptanmadı. 
Sonuç: Çalıșmamızda aritmi belirteçleri olarak değerlendirdiğimiz Pmaks, Pdis, QTd, QTdis, Tp-e, Tp-e/QT hasta grubunda kontrol grubuna göre belirgin artmış izlenmiş ve bu da bu hastaların hem atriyal fibrilasyon hem de ventriküler aritmiler açısından risk altında olduğunu göstermiştir.

Anahtar sözcükler: Aritmi, ani kardiyak ölüm, dispersiyon, elektrokardiyografi

\section{INTRODUCTION}

The prevalence of congenital heart diseases (CHD) is known as $0,5-0,8 \%$ live birth $^{1}$. Its incidence is $3-4 \%$ at stillbirths, $10-25 \%$ at abortuses and $2 \%$ without including patent ductus arteriosus, mitral valve prolapse, bicuspid aortic valve $^{2}$. In a study carried out with adult age group, arrhythmias of congenital heart diseases have been shown to be the second most common cause of mortality following arrhythmias due to ischemic diseases in terms of cardiac death ${ }^{3}$. In the presence of diseases forming obstruction in the exit way of left ventricle (LVEWO) as aorta coarctation (AC), hypertrophic cardiomyopathy (HCM) and aortostenosis (AS); the burden of left ventricle increases prominently and as a result of this increased wall stress in early term and late compensatory ventricular hypertrophy appear ${ }^{4,5}$. All of these can impair ventricle and atrial transmission and lead to predisposition to arrhythmias. In all derivations, the difference between maximum ( $\mathrm{P}$ max) and minimum ( $\mathrm{P}$ min) durations were defined as wave dispersion ( $\mathrm{P}$ dis) by measuring $\mathrm{P}$ wave duration. The presence of heterogenous and variable atrial electrical activity boosts atrial reentry formation. Therefore, $\mathrm{P}$ dis reflects atrial fibrillation development possibility ${ }^{6}$.

QT interval is defined as a distance between the beginning of QRS complex and end of $\mathrm{T}$ wave .QT interval reflects the total durations of ventricle depolarization and repolarization ${ }^{7}$. QT dispersion (QT dis), however, is defined as the difference between the longest duration and shortest QT duration in electrocardiography derivation ${ }^{7,8}$. QT dispersion is a parameter that is brought forward as an indicator of spatial dispersion of recovery durations of suggested ventricle to determine the differentiation from myocardium showing homogeneous conduction of myocardium displaying nonhomogenous conduction. QT dis is thought to reflect regional differences in ventricle repolarization and be an indicator for rhythm disorders 9 .

$\mathrm{T}$ wave is a reflecting form of ventricular repolarization to ECG. The duration between the point that $\mathrm{T}$ wave reaches the maximum amplitude and end of $\mathrm{T}$ wave (Tp-e interval) corresponds to ventricular repolarization dispersion $^{10,11}$.The increase in ventricular repolarization dispersion is an important risk factor for ventricular arrhythmias. Therefore, Tp-e interval is a non-invasive scanning method for arrhythmogenesis. Tp-e interval and Tp-e/QT rate as more definite and more accurate can be approved as an index in terms of sudden cardiac death display ${ }^{12,13}$.

In this study, we aimed to reveal the predisposition to arrhythmias that has a possibility to cause sudden cardiac death in coarctation of the aorta and in the cardiac pathologies (AS, HCM) leading to obstruction in the left ventricle exit way in childhood. To that end, children with these diseases and healthy controls were compared with regard to atrial arythmia and atrial fibrillation as an indicator of P dis, QT dis as a token of ventricular repolarization impairment, Tp-e interval and Tp-e/QT rates.

\section{MATERIAL AND METHODS}

Study Population: A total of 101 patients diagnosed by Dr. Behçet Uz Pediatric Diseases and Surgery Training and Research Hospital Pediatric Cardiology Department between 20082014 and followed up due to cardiac pathology (AS, AC, HCM) that can lead to obstruction in the exit way of left ventricle. The study protocol was approved by Dr. Behçet Uz Pediatric Diseases and Surgery Training and Research Hospital local ethical committee in March 2014. (Approval number: 14/28-3). Written informed consent was obtained from the parents.

Patients with non-cardiologic additional diseases, those with chronic drug use history not for their disease that is primarily followed up by Pediatric Cardiology Department, those diagnosed with arrythmia during their monitoring or using antiaritmic drugs owing to this reason or those with use history were excluded from the study.

As control group; a total of 110 healthy pediatric patients who had been guided to Pediatric Cardiology Polyclinic for murmur or chest pain etiology and as a result of workups conducted those with innocent murmur or those whose chest pain could not be linked to organic reasons, those who had been similar in accordance with their age and gender distribution, Those with no additional diseases or chronic drug use history were involved in the study.

Electocardiography examinations were carried out with two dimensional and coloured Doppler echocardiography device (Vivid 3 Pro, GE 
Medical Systems, NE®). Echocardiographic evaluation was performed by an experienced pediatric cardiologist to all cases involved in the study. After patients had been rested for 10 minutes, they were performed measurements in supine position with standard 12-tipped ECG (Cardiofax GEM, Model 9022K; Nihon Kohden, Tokio, Japan) and $25 \mathrm{~mm} / \mathrm{sec}$ speed and 10 $\mathrm{mm} / \mathrm{mV}$ amplitude. ECG records were scanned and transferred to a personal computer. To increase the accuracy of the measurements; they were taken directly in milimeters after they had been zoomed as $\mathrm{x} 400$ rate by using Adobe Photoshop.

Heart rate, P dis, QT interval, QTd, QT dis, Tp-e and Tp-e/QT were calculated. The data with DIDII-DIII-aVR-aVF-aVL-V1-V2-V3-V4-V5-V6 derivations were examined in ECG with standard 12 derivations.

In every derivation, the duration between the start and end of every sequential $P$ wave was calculated as millisecond and taken its average ( $\mathrm{P}$ wave). Of all derivations, the difference between the longest and shortest $\mathrm{P}$ wave was calculated (Pdis). QT interval is accepted as the distance between the beginning of QRS complex and the end of $\mathrm{T}$ wave. No measurement could be carried out in derivations in which $\mathrm{T}$ wave could not be chosen. When $\mathrm{T}$ wave is two-notched, and if the second notch is smaller than the first wave, the point that the first wave reaches isoelectric line was approved as the end of $\mathrm{T}$ wave. ECGs where all measurements could be performed in at least 9 derivations were taken into consideration. In every derivation, the duration from the outset of $\mathrm{Q}$ wave to the end of $\mathrm{T}$ wave of three beats occuring successively was calculated as millisecond (msec) and its average was taken (QT interval). The difference between the longest QT and the shortest QT duration in all derivations was calculated (QT dis). QTd was calculated with Bazzet formula by benefiting from the same QT waves. By calculating ventricle speed of successive three beats in DII derivation, the average was taken and average heart rate of every patient was determined.

The effects of clinical and demographical characteristics of patients on Pdis, QT interval, QTs, Qtdis and Tp-e interval and Tp-e/QT were examined. In accordance with these parameters, patient group -control group and patient group within themselves according to their diognoses were compared .

Statistical analyses were performed in SPSS 15.0 for Windows statistical analysis package programme. The data were presented as average \pm standard deviation. Independent group t test was used in the comparisons between two groups; Mann Whitney U test was utilized when nonparametric conditions were met; Anova was used when more than two groups were compared and Kruskal Wallis test when non-parametric conditions were met; Boferroni correction test as post Hoc test and chi square test was utilized in the comparison of intergroup rates. In the study, $\mathrm{p}<0.05$ was considered statistically significant.

\section{RESULTS}

A total of 101 patients $(47,9 \%)$ and 110 control $(52,1 \%)$ were involved in the study. The demographical characteristics of patient and control groups were given in Table 1 . The average age of patient group was $109,9 \pm 68,3$ months, and that of control group was $98,9 \pm 55,8$ months. The mean age of patient and control groups were 106 and 108 months, respectively. No statistically significant difference was determined in terms of the average of age between patient and control groups $(\mathrm{p}=0,201)$. There were 69 females and 32 males in patient groups and 68 females and 42 males in control group. No statistically significant difference was established in terms of gender distribution between patient and control groups $(\mathrm{p}=0,323)$.

Table 1. Demographic Features of the Patient and Control Group

\begin{tabular}{|l|l|l|l|}
\hline & Patient group & Control group & $\mathrm{p}$ \\
\hline Number (\%) & $101(47.9)$ & $110(52.1)$ & \\
\hline Age (months) (mean \pm SD) & $109.9 \pm 68.3$ & $98.9 \pm 55.8$ & 0.201 \\
\hline Median age - month (min-max) & $106(1-216)$ & $108(2-216)$ & \\
\hline Gender (male / female) (n/\%) & $69 / 32-(58.3 / 31.7)$ & $68 / 42-(61.8 / 38.2)$ & 0.323 \\
\hline
\end{tabular}


Table 2. Patient Group's Diagnoses

\begin{tabular}{|l|c|c|}
\hline Diagnosis & $\mathrm{N}$ & $(\%)$ \\
\hline Aortic stenosis & 43 & 42.6 \\
\hline $\begin{array}{l}\text { Idiopathic hypertrophic subaortic } \\
\text { stenosis }\end{array}$ & 2 & 2.0 \\
\hline Hypertrophic cardiomyopathy & 16 & 15.8 \\
\hline Aortic coarctation & 40 & 39.6 \\
\hline Total & 101 & 100.0 \\
\hline
\end{tabular}

While there was a beta blocker use in 94 patients out of 101, 7 patients were not receiving beta blocker treatment. 41 patients with aort stenosis, 15 with HCM, 36 with AC were using beta blocker, on the other hand, 2 with AS, 1 with $\mathrm{HCM}$ and 4 with AS were not using beta blocker treatment.
Both 2 patients diagnosed with IHSS were receiving beta blocker treatment. In the grouping according to the existing data, no statistically significant difference was identified in terms of beta blocker use between groups $(p=0,779)$. The data related to beta blocker use in patient group were given in Table 3.

Table 3. Usage of Beta Blockers in the Patient Group

\begin{tabular}{|l|c|c|c|c|c|c|}
\hline & AC & IHSS & HCM & AS & TOTAL & p \\
\hline Beta blocker (+) & 41 & 2 & 15 & 4 & 94 & \multirow{2}{*}{0.779} \\
\hline Beta blocker(-) & 2 & 0 & 1 & 4 & 7 & \\
\hline Total & 43 & 2 & 16 & 40 & 101 & \\
\hline
\end{tabular}

While there was operation/intervention history in 38 out of 101 patients, there was no operation/intervention history in 63 patients. There was a baloon or stent application history in 20 out of 38 patients, on the other hand, 18 patients had an operation. While there was an intervention history such as baloon or stent application in 17 patients with aort stenosis, 1 with IHSS, 2 with AC, those all of the patient who had an operation were with AC. In all 16 patients diagnosed with hypertrophic cardiomyopathy, 26 with AS, 1 with IHSS and 20 with AC, there was no intervention or operation history.

In the grouping of present diagnoses, there was a statistically significant difference with regard to operation/intervention history between groups $(\mathrm{p}=0,000)$. The data associated with 
operation/intervention history in patient group

were given in Table 4 .

Table 4. Operation / Intervention Story in Patient Group

\begin{tabular}{|l|c|c|c|c|c|c|}
\hline $\begin{array}{l}\text { Operation / } \\
\text { Intervention story }\end{array}$ & AS & IHSS & HCM & AC & TOTAL & p \\
\hline Intervention & 17 & 1 & 0 & 2 & 20 & \multirow{2}{*}{0.000} \\
\hline Operation & 0 & 0 & 0 & 18 & 18 & 63 \\
\hline None & 26 & 1 & 16 & 20 & 101 & \\
\hline Total & 43 & 2 & 16 & 40 & \\
\hline
\end{tabular}

Patient and control group were compared in terms of heart rate, PR and QRS durations (Table VIII). Heart rates in patient and control groups were $101,8 \pm 32,0$ and $102,7 \pm 24,3$ respectively and they were similar $(p=0,825)$. When they were evaluated in terms of their PR durations, the average PR duration was $138,7 \pm 23,3 \mathrm{~ms}$ in patient group, in control group it was idnetified as $127,0 \pm 15,6 \mathrm{~ms}$ and PR duration was significantly longer than that of control group in patient group $(p=0,000)$. When they were evaluated in terms of their QRS durations, the average QRS duration in patient group was 79,8 $\pm 17,7 \mathrm{~ms}$, the average QRS duration in control group was determined as $78,6 \pm 8,7 \mathrm{~ms}$ and it was similar $(\mathrm{p}=0,526)$.

$\mathrm{P}$ max value was $98,4 \pm 20,3 \mathrm{~ms}$ in patient group and $84,8 \pm 20,1 \mathrm{~ms}$ in control group. Statistically significant difference was determined in terms of $\mathrm{P}$ max value between two groups $(\mathrm{p}=0,000)$. In comparisons carried out in terms of $\mathrm{P}$ dis in patient and control groups, patient group values for this indicator was established significantly higher than those of control group and the difference for intergroup was statistically significant in terms of this indicator $(\mathrm{p}=0,000)$ (Table 5).

QTd was determined explicitly lower in the control group compared to patient group and this difference was statistically significant (respectively 422,5 $\pm 34,6 \mathrm{~ms}, 390,0 \pm 23,8 \mathrm{~ms}$ and $\mathrm{p}=0,000)$. In comparisons carried out in patient and control groups with regard to Qt dis, patient group values for this indicator were established distinctly higher and the intergroup difference in terms of this was statistically significant $(\mathrm{p}=0,000)($ Table 6$)$.

When Tp-e value was proportioned with QT, Tpe/QT rate was $0,25 \pm 0,059$ in control group while it was $0,28 \pm 0,062$ in patient group. Statistically significant difference was established between both groups' Tp-e/QT rates $(\mathrm{p}=0,002)$ (Table 7).

Table 5. Pmax, Pmin ve Pdis in Patients and Control Groups

\begin{tabular}{|l|l|c|c|c|}
\hline & Groups & $\mathrm{n}$ & mean \pm SD & $\mathrm{p}$ \\
\cline { 1 - 4 } Pmax(ms) & patient & 101 & $98.4 \pm 20.3$ & \multirow{2}{*}{0.000} \\
\cline { 2 - 4 } & control & 110 & $84.8 \pm 20.1$ & \\
\hline Pmin (ms) & patient & 101 & $63.6 \pm 20.4$ & 0.675 \\
\cline { 1 - 4 } & & 101 & $34.8 \pm 16.9$ & 0.000 \\
\hline
\end{tabular}


Table 6. QTmaks, QTmin, QTd ve QT dis in Patients and Control Groups

\begin{tabular}{|l|l|c|c|c|}
\hline & Groups & $\mathrm{n}$ & Mean \pm SD & $\mathrm{p}$ \\
\hline \multirow{2}{*}{ QTmax (ms) } & patient & 101 & $347.3 \pm 45.2$ & \multirow{2}{*}{0.315} \\
\cline { 2 - 4 } & control & 110 & $342.1 \pm 27.1$ & \\
\hline QTmin (ms) & patient & 101 & $297.2 \pm 42.5$ & \multirow{2}{*}{0.005} \\
\cline { 2 - 4 } & control & 110 & $312.1 \pm 32.5$ & \multirow{2}{*}{0.000} \\
\hline QTd (ms) & patient & 101 & $422.5 \pm 34.6$ & \multirow{2}{*}{0.000} \\
\cline { 2 - 4 } & control & 110 & $390.0 \pm 23.8$ & \\
\hline QTdis (ms) & patient & 101 & $50.1 \pm 20.4$ & \\
\cline { 2 - 4 } & control & 110 & $30.0 \pm 20.6$ & \\
\hline
\end{tabular}

Table 7. Tp-e ve Tp-e/QT in Patients and Control Groups

\begin{tabular}{|l|l|l|l|l|}
\hline & Groups & $\mathrm{n}$ & Mean \pm SD & $\mathrm{p}$ \\
\hline Tp-e (ms) & patient & 101 & $96.1 \pm 22.2$ & \multirow{2}{*}{0.000} \\
\cline { 2 - 5 } & control & 110 & $85.9 \pm 19.1$ & \\
\hline Tp-e/QT & patient & 101 & $0.28 \pm 0.062$ & 0.002 \\
\hline
\end{tabular}

In the one by one comparison of Pmax, QTd, P dis, QT dis, Tp-e and Tp-e/QT indices of AS, IHSS, HCM, AC groups which are subgroups of patient group, no statistically significant difference was determined between groups.

Pmax, P dis, QTd, Qtdis, Tp-e, Tp-e/QT that are arrythemia indicators were compared in patient groups with and without use of beta blocker. No significant difference was identified in terms of these parameters in patient groups with and without use of beta blocker. (Table 8)

In the comparison of operation/intervention history presence and Pmax, Pdis, QTd, QTdis, Tp$\mathrm{e}, \mathrm{Tp}-\mathrm{e} / \mathrm{QT}$ in patient group, it reveals that atrial arrhythmia risk is higher in those with operation/intervention history than those without such history.(Table 9) 
Table 8. Pmax, Pdis, QTd, QTdis, Tp-e, Tp-e / QT Comparisons in Patients with and without Beta Blockers

\begin{tabular}{|c|c|c|c|c|c|}
\hline & Beta Blocker & $\mathrm{n}$ & Ortalama & $\mathrm{SD}$ & $\mathrm{p}$ \\
\hline \multirow[t]{2}{*}{$\mathrm{P} \max (\mathrm{ms})$} & beta blocker (-) & 7 & 100.0 & 20.0 & \multirow{2}{*}{0.827} \\
\hline & beta blocker (+) & 94 & 98.2 & 20.4 & \\
\hline \multirow[t]{2}{*}{ Pdis (ms) } & beta blocker (-) & 7 & 41.4 & 12.1 & \multirow{2}{*}{0.285} \\
\hline & beta blocker (+) & 94 & 34.3 & 17.1 & \\
\hline \multirow[t]{2}{*}{ QTd (ms) } & beta blocker (-) & 7 & 442.7 & 28.6 & \multirow{2}{*}{0.109} \\
\hline & beta blocker (+) & 94 & 420.9 & 34.7 & \\
\hline \multirow[t]{2}{*}{ QTdis (ms) } & beta blocker (-) & 7 & 61.4 & 21.9 & \multirow{2}{*}{0.129} \\
\hline & beta blocker (+) & 94 & 49.2 & 20.1 & \\
\hline \multirow[t]{2}{*}{ Tp-e (ms) } & beta blocker (-) & 7 & 95.7 & 21.5 & \multirow{2}{*}{0.958} \\
\hline & beta blocker (+) & 94 & 96.2 & 22.3 & \\
\hline \multirow[t]{2}{*}{ Tp-e/QT } & beta blocker (-) & 7 & 0.25 & 0.07 & \multirow{2}{*}{0.350} \\
\hline & beta blocker (+) & 94 & 0.28 & 0.06 & \\
\hline
\end{tabular}

Table 9. Pmax, Pdis, QTd, QTdis, Tp-e, Tp-e / QT Comparisons of Operative / Intervention Story in the Patient Group

\begin{tabular}{|c|c|c|c|c|c|}
\hline & Operation/Intervention & $\mathrm{n}$ & Mean & SD & $\mathrm{p}$ \\
\hline \multirow[t]{3}{*}{$\mathrm{P} \max (\mathrm{ms})$} & Operation/Intervention(-) & 63 & 96.9 & 20.2 & \multirow{3}{*}{0.655} \\
\hline & Intervention(+) & 20 & 99.7 & 21.6 & \\
\hline & Operation(+) & 18 & 101.6 & 19.7 & \\
\hline \multirow[t]{3}{*}{ Pdis (ms) } & Operation/Intervention(-) & 63 & 31.7 & 13.9 & \multirow{3}{*}{0.017} \\
\hline & Intervention(+) & 20 & 35.7 & 20.2 & \\
\hline & Operation(+) & 18 & 44.4 & 19.4 & \\
\hline \multirow[t]{3}{*}{ QTd (ms) } & Operation/Intervention(-) & 63 & 426.5 & 36.0 & \multirow{3}{*}{0.190} \\
\hline & Intervention(+) & 20 & 420.8 & 21.7 & \\
\hline & Operation(+) & 18 & 409.8 & 39.5 & \\
\hline \multirow[t]{3}{*}{ QTdis (ms) } & Operation/Intervention(-) & 63 & 52.1 & 21.0 & \multirow{3}{*}{0.435} \\
\hline & Intervention(+) & 20 & 48.0 & 19.6 & \\
\hline & Operation(+) & 18 & 45.5 & 19.1 & \\
\hline \multirow[t]{2}{*}{ Tp-Te (ms) } & & & & & \\
\hline & Operation/Intervention(-) & 63 & 96.6 & 22.5 & 0.773 \\
\hline
\end{tabular}




\section{DISCUSSION}

Congenital heart diseases are an important morbidity and mortality reason. In a study carried out, arrhythmias related to congenital heart diseases are shown to be the most common cause of mortality in terms of sudden cardiac death after arrhythmias depending on ischemic diseases ${ }^{3}$. In the presence of diseases forming obstruction in the left ventricle exit way such as aorts coarctation (AC), hypertrophic cardiomyopathy (HCM) and aortostenosis (AS), left ventricle after load raises distinctly and as a result of this, increased wall stress in early period and late compensatory ventricle hypertrophy appear ${ }^{4,5}$. All these can form a predisposition to arrhythmias by impairing ventricle and atrial conduction. There are many studies evaluating P max, P dis, QT dis and Tp-e and Tp-e/QT in adult and child age group in various patient groups in literature and it is pointed out in these studies that these indices are successful in displaying atrial or ventricular arrhythmias.

In our study, it was aimed to manifest the predisposition to arrhythmias that may lead to sudden cardiac death in aort coarctation and cardiac pathologies causing obstruction in left ventricle exit way (AS, HCM) in childhood. To that end, the children with these diseases and healthy controls were compared in terms of $\mathrm{P}$ dis as an indicator of atrial arrhythmia and atrial fibrillation; Qt dis, Tp-e interval and Tp-e/QT rates as an indicator of ventricular repolarization impairment.

Determined arrhythmia presence is one of the reasons of patients' not being involved in the study in the patient group included in the study. Therefore, there is no obvious arrhythmia in none of the patients involved in the study as a patient group or they receive no treatment for this purpose. In this study, the difference to be determined compared to control group in Pmax, QTd, Pdis, QTdis, Tp-e and Tp-e/QT indices that are arrhythmia indicators will be an important warning for arrhythmia risk which is likely in individuals without evident arrhythmia.

$\mathrm{P}$ wave dispersion is defined as the difference between the longest and shortest $\mathrm{P}$ wave duration in ECG derivations. Irregular and intermittent atrium conduction in patients with paroxysmal atrial fibrillation are evaluated with $\mathrm{P}$ dis ${ }^{14}$. In that studies by Dilaveris et al.22 and Aytemir et al.24 determined $\mathrm{P}$ dis value longer in those with atrial fibrillation history compared to that of healthy individuals. In many studies, $\mathrm{P}$ dis and $\mathrm{P}$ max values are identified significantly higher in patients with paroxysmal atrial fibrillation ${ }^{15-22}$. There are studies related to $\mathrm{P}$ wave duration and $\mathrm{P}$ dis carried out in children ${ }^{23,24,25}$. In a study performed in children with secundum ASD, $\mathrm{P}$ dis value $(30,2 \pm 11,1 \mathrm{~ms})$ was shown to have increased significantly than healthy children $(26,4 \pm 6,6 \mathrm{~ms})$ at the same age ${ }^{26}$. These patients were emphasized to be followed up in terms of atrial arrhythmia. In another study, $\mathrm{P}$ dis value in patients with rheumatic mitral valve obstruction was found significant in displaying atrial fibrillation risk and this significance reduced with the long use of beta blocker in these patients ${ }^{19}$. In our study, however, no significant difference was identified between $P$ $\max$ and $\mathrm{P}$ dis values of patients using beta blocker and not using beta blocker; on the other hand, $\mathrm{P}$ max and $\mathrm{P}$ dis values of both groups were shown to be longer than those of control group. These results show that unlike some other studies' results in literature, the effect of beta blocker use on Pmax and Pdis values; thereby sudden death risk depending on atrial fibrillation risk may not be evident.

A simpler method assessing the change in cardiac sympathetic inervation is the QT interval measurement. QT analysis is a simple, inexpensive and non-invasive test requring no patient conformity. QT interval shows the total duration of myocardial depolarization and repolarization. Kautzner et al.27 indicated that QTd singly could be more related to ventricular arrhythmia risk compared to QT interval. The relationship between extended QT interval and increased sudden death risk was reported in familial long QT syndrome, sudden infant death and ischemic heart disease ${ }^{28}$. The close connection between QT dispersion - the criterion of regional differences in ventricular repolarization durationand ventricular ritm impairments are reported in various studies ${ }^{29,30,31}$. In two studies performed in patients with isolated AS, long QTdis values were established. In a study carried out with newborns, QTdis values were shown to increase apparently in patients with $\mathrm{AC}^{32,33}$. In our study, it was determined that there was an increase in corrected QT distance and QT dispersion in patient group compared to healthy children. As a result, in children with cardiac pathology as LVEWO; increased QT dispersion can be a beneficial indicator in evaluating ventricular ritm impairment.

$\mathrm{T}$ wave is the reflection shape of ventricular repolarization to ECG. The duration between the point that $\mathrm{T}$ wave reaches maximum amplitude and the end of $\mathrm{T}$ wave (Tp-e interval) corresponds to ventricle repolarization dispersion ${ }^{10,11,12}$. The 
increase in ventricle repolarization dispersion is an important risk factor for venricular arrhythmias. Therefore, Tp-e interval is a noninvasive scanning method for arrhythmogenesis and Tp-e interval can be approved as a crucial index in showing sudden cardiac death risk. There are studies in literature displaying that Tp-e/QT rate independent from $\mathrm{Tp}$-e is a more reliable and stable inde $\mathrm{x}^{34,35}$. In a study that Tp-e/QT rate and its use were assessed, measurements were carried out in 60 healthy volunteers and it was shown that Tp-e interval decreased in a linear way with increase in heart rate. However, Tp-e/QT rate remained stable in this study despite the change in heart rate. In this study, Tp-e/Qt rate was determined between 0.15 and 0.25 independent from heart rate $^{34}$. Nevertheless, there is no wellattended study supporting this research related to the approval of data in question. In our study, both Tp-e and Tp-e/QT indices were determined apparently higher in patient group compared to those of control group. This demonstrates that increased ventricular arrhythmia risk was high in patient group.

\section{CONCLUSION}

Pmax, Pdis, QTd, QTdis, Tp-e, Tp-e/QT that we evaluated as arrhythmia indicators with ECG having standard 12 derivations increased distinctly in patient group compared to control group and this indicated that these patients are under risk in terms of both atrial fibrillation and ventricular arrhythmias. No significant difference was determined between Pmax and Pdis values of patients with and without use of beta blocker, however, both groups were found to be longer than control group with regard to Pmax and Pdis values. Contrary to the results of some studies in literature, the effect of beta blocker use on Pmax and Pdis values and consequently on sudden death risk related to AF may not be apparent.

There are some limitations of this study. While choosing patient group involved in the study, those without arrhythmia history were only included in the study and some evaluations were carried out on these patients. This situation prevented the comparison of arrhythmia indicators in patients with and without arrhythmia.

It will present more accurate and precise information if the patients are followed up with Holter device for 24 hours for a definite correlation of this increase with arrhythmia presence in the indices and if the patients diagnosed with arrhythmia are compared those without arrhythmia.

\section{Acknowledgments}

We thank Timur Meşe who supported our work.

\section{REFERENCES}

1. Gürakan B. Konjenital kalp hastalıklarının değerlendirilmesi. In: Yurdakök $M$, Erdem G(ed) Neonataloji. Ankara, 2004;503-512.

2. 2- Bernstein D. Epidemiology and genetic basis of congenital heart disease. In: Berhman RE, Kliegman RM, Jenson HB (ed). Nelson Texbook of Pediatrics W.B. Saunders Company, Philadephia,2008;1549,1502,1610.

3. Koyak Z, Haris L, De Groot JR et al. Sudden Cardiac Death in Adult Congenital Heart Disease. Circulation 2012; 126:1944-1954.

4. Ragsten-Almqvist P, Rajs J.Cardiovascular malformations and sudden death in infancy. Am J Forensic Med Pathol 2004;25:134-140.

5. Zabel M, Portnoy S, Franz MR. Electrocardiographic indexes of dispersion of ventricular repolarization: an isolated heart validation study. J Am Coll Cardiol 1995;25:746-752

6. Lepeschkin E, Surawicz B. The measurement of the Q-T interval of the electrocardiogram. Circulation 1952;6:378-88

7. Funck-Brentano C, Jaillon P. Rate-corrected QT interval: techniques and limitations. Am J Cardiol 1993;72(6):17-22.

8. Malik M, Batchvarov V . Measurement, interpretation and clinical potential of QT dispersion. J AmColl Cardiol 2000;36: 174966.

9. Kautzner J, Marek M.QT interval dispersion and its clinical utility. PACE 1997; 20:26252640.

10.Antzelevitch $\mathrm{C}$. $\mathrm{T}$ peak-Tend interval as an index of transmural dispersion of repolarization. Eur J Clin Invest 2001; 31:555.

11.Antzelevitch $\mathrm{C}$. The role of spatial dispersion of repolarization in inherited and acquired sudden cardiac death syndromes. Am J Physiol Heart Circ Physiol 2007; 2:101-102.

12.Gupta P, Patel C, Patel $\mathrm{H}$ et al. Tp-e/QT ratio as an index of arrhythmogenesis. Journal of Electrocardiology 2008;41:567-574.

13.Edwards W D. Classification and terminology of cardiovascular anomalies. In: Allen HD, Gutgesell HP, Clark EB, Driscoll DJ (ed) Moss \& Adams Heart Disease in Infants, Children, and Adolescent including the Fetus and Young Adult, Lippincott Williams and Wilkins. Philadelphia, 2001;118-137. 
14.Kose S, Kilic A, Iyisoy A, Kursaklioglu H, Lenk MK. $P$ wave duration and $p$ dispersion in healthy children. Turk J Pediatr 2003; 45(2): 133-135.

15.Guray U, Guray Y, Mecit B, Y1lmaz MB, Sasmaz H, Korkmaz S. Maximum p wave duration and $\mathrm{p}$ wave dispersion in adult patients with secundum atrial septal defect: the impact of surgical repair. Ann Noninvasive Electrocardiol 2004;9(2):136-141.

16.Turhan $\mathrm{H}$, Yetkin E, Atak R, et al. Increased $\mathrm{p}$ wave duration and $\mathrm{p}$ wave dispersion in patients with aortic stenosis. Ann Noninvasive Electrocardiol 2004; 8:18-21.

17. Ozdemir O, Soylu M, Demir AD. P wave durations as a predictor for atrial fibrillation development in patients with hypertrophic cardiomyopathy. Int J Cardiol 2004; 94(2-3): 163- 166.

18.Ozer N, Aytemir K, Atalar E, et al. P dispersion in hypertensive patients with paroxysmal atrial fibrillation. Pacing Clin Electrophysiol 2000;23(pt.II):1859-62.

19.Erbay AR, Turhan H, Yasar AS, et al. Effects of long-term beta-blocker therapy on pwave duration and dispersion in patients with rheumatic mitral stenosis. Int J Cardiol 2005; 102: 33-7.

20.Boriani G, Diemberger I, Biffi M, et al. P wave dispersion and short-term vs. late atrial fibrillation recurrences after cardioversion. Int J Cardiol 2005; 101: 355-61.

21.Çamsari A, Pekdemir H, Akkus MN, Yenihan S, Döven O, Cin G. Long-term effects of beta bloker therapy on p-wave duration and dispertion in congestive heart failure patients: a new effect. J Electrocardiol 2003; 36(2): 111116.

22.Dilaveris PE, Gialafos EJ, Andrikopoulos GK, et al. Clinical and electrocardiographic predictors of recurrent atrial fibrillation. Pacing Clin Electrophysiol 2000;23: 352-8.

23. Guray U, Guray Y, Mecit B, Y1lmaz MB, Sasmaz H, Korkmaz S. Maximum $p$ wave duration and $\mathrm{p}$ wave dispersion in adult patients with secundum atrial septal defect: the impact of surgical repair. Ann Noninvasive Electrocardiol 2004;9: 136-41.

24.Haliloğlu O, Aytemir K, Celiker A. The significance of $\mathrm{p}$ wave duration and $\mathrm{p}$ wave dispersion for risk assessment of atrial tachyarrhythmias in patients with corrected tetralogy of Fallot. Ann Noninvasive Electrocardiol 2004;9: 339-44.

25.Wong T, A. Davlouros P, Li W, et al. Mechano-electrical interaction late after Fontan operation. Relation between $\mathrm{p}$ wave duration and dispersion, right atrial size, and atrial arrhythmias. Circulation 2004;109(19): 2319-25

26. Ho TF, Chia EL, Yip WC, Chan KY. Analysis of $p$ wave and $p$ dispersion in children with secundum atrial septal defect. Ann Noninvasive Electrocardiol 2001;6(4): 305-9.

27.Kautzner J, Malik M. QT interval dispersion and its clinical utility. Pacing Clin Electrophysiol 1997;20:2625-2640.

28.Schwartz PJ. Idiopathic long QT syndrome: progress and questions. Am Heart $\mathbf{J}$ 1982;19:399-411.

29.Kuo CS, Munakata K, Reddy CP, Surawicz B. Characteristics and possible mechanisms of ventricular arrhythmia dependent on the dispersion of action potential duration. Circulation 1983;67: 1356-67.

30.Merx W, Yoon MS, Han J. The role of local disparity in conduction and recovery time on ventricular vulnerability to fibrillation. Am Heart 1997; J 94: 603-10.

31. Cowan CJ, Yussof CK, Moore $\mathrm{M}$, et al. Importance of lead selection in QT interval measurement. Am Heart J 1988;61: 83-7.

32.Sap F, Karatas Z, Altin H et al. Dispersion Durations of P-wave and QT Interval in Children With Congenital Heart Disease and Pulmonary Arterial Hypertension. Pediatric Cardiol 2013;34:591-596.

33.Kose S, Kilic, A, Iyisoy A, Kursaklioglu H, Lenk MK. P-wave duration and $\mathrm{P}$ dispersion in healthy children. Turk J Pediatr 2003;45:133135.

34.Antzelevitch C. Heterogeneity and cardiac arrhythmias: an overview. Heart Rhythm 2007;4:964.

35.Karadeniz $\quad \mathrm{C}^{1}$, Özdemir $\quad \mathrm{R}^{2}$, Demirol $\mathrm{M}^{2}$, Katipoğlu $\mathrm{N}^{3}$, Yozgat $\mathrm{Y}^{2}$, Meşe $\mathrm{T}^{2}$, Ünal $\mathrm{N}^{2}$.Low Iron Stores in Otherwise Healthy Children Affect Electrocardiographic Markers of Important Cardiac Events. Pediatr Cardiol 2017;38(5):909-914. 